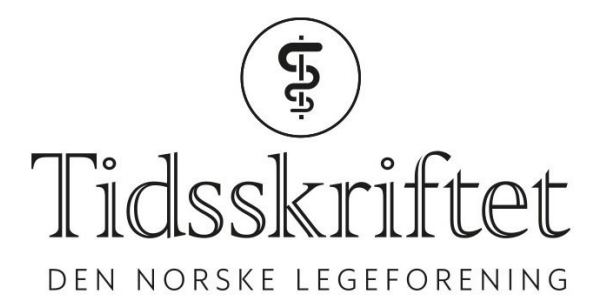

\title{
Tidlig rehabilitering etter subaraknoidalblødning fra aneurisme
}

DOKTORAVHANDLINGER

TANJA KARIC

E-post: tanja.karic@gmail.com

Tidlig rehabilitering etter subaraknoidalblødning fra aneurismer er nyttig og trygt. Det gir færre komplikasjoner og bedre langtidsfunksjon.

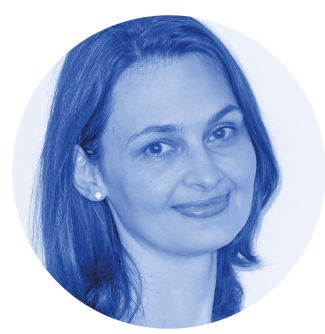

Foto: privat

Frykt for komplikasjoner har gjort at pasienter som behandles for et sprukket aneurisme ikke mobiliseres i vesentlig grad. Den mest fryktede komplikasjonen til subaraknoidalblødning fra aneurismer er vasospasme, hvor blodårene i hjernen trekker seg sammen og i verste fall forårsaker hjerneslag og død.

I mitt doktorgradsarbeid utviklet vi et konsept for tidlig rehabilitering etter subaraknoidalblødning fra aneurismer og undersøkte om det var trygt og hvorvidt det hadde innvirkning på komplikasjonsrate og funksjonsnivå.

Pasienter som ble behandlet for sprukne aneurismer ved Oslo universitetssykehus i 2011 fikk standardbehandling, mens de i 2012 også fikk tidlig rehabilitering. Rehabiliteringstiltakene, som inkluderte heving av hodeenden på sengen utover $30^{\circ}$, startet fra første postoperative dag. Dette førte til en mye større mobilitet ved utskrivning uten å øke komplikasjonsraten. Risikoen for alvorlige vasospasmer var redusert med $30 \%$ for hvert steg på mobiliseringskurven pasienten hadde oppnådd i løpet av de første fire dagene etter at aneurismet ble reparert.

Pasienter med alvorlige subaraknoidalblødninger hadde dobbelt så stor sjanse for å oppnå godt funksjonsnivå etter ett år dersom man utførte tidlig rehabilitering.

Resultatene indikerer at tidlig rehabilitering bør være en integrert del av akuttbehandlingen etter subaraknoidalblødning fra aneurismer. Det bør arbeides videre med hvordan rehabiliteringen skal gjennomføres. 


\section{Disputas}

Tanja Karic disputerte for ph.d.-graden ved Universitetet i Oslo 21.4.2017.

Tittelen på avhandlingen er Early rehabilitation after aneurysmal subarachnoidal hemorrhage.

Publisert: 2. oktober 2017. Tidsskr Nor Legeforen. DOI: 10.4045/tidsskr.17.0544

(C) Tidsskrift for Den norske legeforening 2020. Lastet ned fra tidsskriftet.no 